\title{
KAJIAN TENTANG VARIASI KONSENTRASI NaCI DENGAN KETERSEDIAAN ENERGI LISTRIK PADA SEL VOLTA Cu-Zn
}

\author{
Tria Winarsih ${ }^{1}$, Ishak Semuel Erari ${ }^{2}$, Abdul Muis Muslimin ${ }^{3}$ \\ email: 1) triawinarsih05@gmail.com,2) ishakerari@yahoo.com,3) a.muslimin@unipa.ac.id \\ ${ }^{1,2,3}$ Prodi Fisika Jurusan Fisika FMIPA UNIPA
}

\begin{abstract}
ABSTRAK
Kajian Tentang Variasi Konsentrasi $\mathrm{NaCl}$ Dengan Ketersediaan Energi Listrik Pada Sel Volta $\mathrm{Cu}-\mathrm{Zn}$ bertujuan untuk menganalisa hubungan antara jumlah sel volta $\mathrm{Cu}-\mathrm{Zn}$ terhadap besar arus listrik dan tegangan listrik, perubahan arus listrik, tegangan listrik dan daya listrik terhadap waktu, jumlah akumulasi energi pada sel volta $\mathrm{Cu}-\mathrm{Zn}$ terhadap beberapa konsentrasi $\mathrm{NaCl}(0,001 \mathrm{M} ; 0,01 \mathrm{M} ; 0,1 \mathrm{M} ; 1 \mathrm{M} ; 10 \mathrm{M})$. Hasil penelitian ini diketahui semakin tinggi konsentrasi $\mathrm{NaCl}$ maka tegangan yang dihasilkan semakin kecil sebaliknya jika konsentrasi $\mathrm{NaCl}$ tinggi maka arus listrik yang dihasilkan semakin meningkat. Pada penelitian ini konsentrasi $\mathrm{NaCl}$ yang paling baik adalah dengan konsentrasi $1 \mathrm{M}$ dibandingkan dengan konsentrasi $\mathrm{NaCl}$ lainnya.
\end{abstract}

Kata kunci : Sel volta Cu-Zn, Konsentrasi NaCl, Energi listrik, Akumulasi Energi

\section{PENDAHULUAN}

Energi telah ditemukan sebelum tahun 1800-an, telah banyak dampak positif yang dihasilkan dalam berbagai kegiatan manusia. Terdapat banyak bentuk kegiatan dan aktivitas manusia yang menggunakan bantuan energi listrik, mulai dari aktivitas rumah tangga sampai dengan proses produksi pada industri-industri kecil ataupun yang berskala besar (Giancoli, 1998).

Sumber energi yang paling banyak digunakan di dunia adalah energi fosil yang merupakan bahan bakar minyak. Indonesia saat ini sangat bergantung pada bahan bakar fosil. Energi fosil adalah energi yang tak terbarukan dan akan habis pada beberapa tahun yang akan datang. Selain karena akan habis, energi fosil juga berdampak negatif terhadap lingkungan. Emisi gas rumah kaca dari pembakaran energi fosil berdampak pada pemanasan global yang menyebabkan perubahan iklim.

Energi tidak akan lepas dari kehidupan manusia. Konsumsi energi yang sedemikian tinggi menyebabkan sumber energi minyak bumi semakin menipis, oleh karena itu perlu adanya energi alternatif. Sumber energi alternatif bertujuan untuk menggantikan sumber energi yang tidak dapat diperbarukan. Dalam penggunaan air garam sebagai sumber energi listrik dapat dilakukan dengan metode sel elektrokimia. Sel elektrokimia adalah suatu alat yang dapat menghasilkan arus listrik dari energi yang dihasilkan oleh reaksi didalam selnya, yaitu berupa reaksi reduksi oksidasi. Dengan adanya reaksi reduksi dan oksidasi ini maka akan menghasilkan arus listrik yang biasa disebut dengan energi listrik. Sel elektrokimia dapat berupa sel volta dan sel elektrolisis.

Pada sel volta maupun sel elektrolisis selain terdapat larutan 
elektrolit, juga terdapat katoda dan anoda. Katoda dan anoda inilah yang berfungsi sebagai tempat terjadinya reaksi reduksi dan oksidasi, serta sebagai penghantar dari energi listrik yang dihasilkan dari reaksi kimia yang terjadi antara garam dan air. Bila dua buah elektroda dihubungkan dengan konduktor listrik maka akan terjadi rangkaian yang sempurna dan meter bergerak.

Penelitian Yulianti (2016) dengan sel volta yang tersusun dari elektroda tembaga $(\mathrm{Cu})$, besi $(\mathrm{Fe})$, aluminium (Al) dan seng ( $\mathrm{Zn}$ ) dengan media agar-agar dan larutan elektrolit garam $\mathrm{NaCl}$. Pasangan elektroda yang digunakan yaitu $\mathrm{Cu}-\mathrm{Al}, \mathrm{Cu}-$ Fe, $\mathrm{Cu}-\mathrm{Zn}, \mathrm{Al}-\mathrm{Zn}$ dan Fe-Zn. Hasil penelitian dianalisis nilai arus, tegangan dan daya dengan hasil paling besar pada pasangan elektroda $\mathrm{Cu}-\mathrm{Zn}$. Tembaga $(\mathrm{Cu})$ dan seng (Zn) juga memiliki nilai potensil elektroda standar lebih baik jika dibandingkan dengan pasangan elektroda lainnya. Demikian pula hasil penelitian Pauzi dkk (2016) terhadap variasi elektroda $\mathrm{C}, \mathrm{Zn}, \mathrm{Al}$ dan $\mathrm{Cu}$ menunjukkan bahwa pasangan elektroda $\mathrm{Cu}-\mathrm{Zn}$ menghasilkan tegangan lebih tinggi jika dibandingkan dengan kombinasi elektroda lainnya. Tembaga $(\mathrm{Cu})$ dan seng $(\mathrm{Zn})$ merupakan logam yang mudah ditemukan dan diperoleh dipasaran.

Air garam merupakan elektrolit yang memiliki daya hantar listrik yang baik sehingga dapat digunakan sebagai salah satu komponen sel volta untuk menghasilkan energi listrik (Sastrohamidjojo, 2005). Menurut Hariyani dkk (2013) konsentrasi ion menentukan banyaknya ion yang terdapat dalam larutan, semakin besar konsentrasinya maka semakin banyak ion dalam larutan tersebut, dengan semakin besar konsentrasi berarti gaya dorong yang dihasilkan oleh ion-ion pada larutan elektrolit terhadap permukaan elektroda semakin besar. Menurut Supriadi dalam Zikriana dkk (2017) menyatakan semakin banyak jumlah ion yang terkandung dalam larutan elektrolit maka akan semakin besar pula daya hantar listriknya. Namun menurut Sani (2018) konsentrasi elektrolit mempengaruhi kadar keasinan, semakin banyak garam yang digunakan maka tegangan listrik yang dihasilkan juga akan semakin kecil. Semakin lama waktu elektrolisis maka semakin turun efisiensi karena hambatan elektrolit semakin meningkat, dan arus yang digunakan akan semakin kecil.

\section{METODE PENELITIAN}

Penelitian ini dilaksanakan dari bulan Juni 2019 sampai dengan Februari 2020 di Laboratorium Fisika FMIPA Universitas Papua (UNIPA). Penelitian ini dimulai dari studi literatur, perancangan alat, pengambilan data, pengolahan data dan analisis data. Studi literatur merupakan tahapan awal untuk mencari literatur mengenai penelitian. Perancangan alat merupakan tahapan kedua untuk membuat rangkaian elektroda dan larutan elektrolit garam dapat ditunjukkan pada gambar berikut.

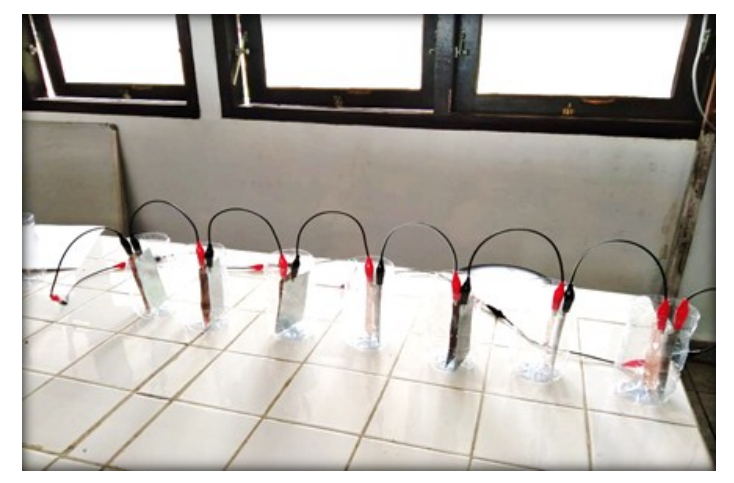

Gambar 1. Pembuatan Rangkaian Sel Volta

Pengambilan data dalam bentuk data primer. Data primer diperoleh dari pengukuran langsung di laboratorium fisika berupa pengukuran tegangan listrik, 
arus listrik dan intensitas cahaya. Pengukuran arus listrik dan tegangan listrik secara seri dan paralel yang bertujuan untuk mengetahui pengaruh konsentrasi larutan elektrolit terhadap nilai arus dan tegangan. Selanjutnya pengukuran arus listrik, tegangan listrik dan intensitas cahaya penurunan terhadap waktu perhari. Tahap pengolahan data merupakan data-data yang sudah dikumpulkan kemudian diolah menjadi informasi yang diperlukan dan analisis data merupakan tahapan akhir dari penelitian. Analisis data akan diplot dalam bentuk grafik yang dibuat menggunakan microsoft excel. Besaran fisis yang akan dianalisis antara lain: arus listrik, potensial listrik, daya listrik dan akumulasi energi.

\section{HASIL DAN PEMBAHASAN}

Hasil pengujian konsentrasi $\mathrm{NaCl}$ : 0,001 M, 0,01 M, 0,1 M, $1 \mathrm{M}$ dan $10 \mathrm{M}$ di dalam sel volta $\mathrm{Cu}-\mathrm{Zn}$ dengan luas elektroda sebesar $50 \mathrm{~cm}^{2}$ dengan jarak antara kedua elektroda $1 \mathrm{~cm}$ yaitu diperoleh jumlah sel volta terhadap waktu pada rangkaian seri maupun rangkaian paralel. Jumlah arus listrik, potensial listrik dan daya listrik terhadap waktu. Jumlah daya listrik terhadap waktu dan akumulasi energi terhadap waktu. Pada penelitian ini katoda yang digunakan adalah tembaga sedangkan anoda yang digunakan adalah seng. Hasil yang diperoleh untuk nilai arus listrik dan potensial listrik bervariasi tergantung dari konsentrasi $\mathrm{NaCl}$ terhadap luas elektroda tembaga dan seng tersebut.

\section{Konsentrasi Garam dan Daya Hantar}

\section{Listrik}

DHL merupakan daya hantar listrik suatu benda atau suatu zat dan kemampuan benda itu sendiri untuk dapat menghantarkan listrik (Latifah, 2014).
Garam $(\mathrm{NaCl})$ diambil beberapa konsentrasi yaitu $0,001 \mathrm{M} ; 0,01 \mathrm{M} ; 0,1 \mathrm{M}$; $1 \mathrm{M}$ dan $10 \mathrm{M}$ dari konsentrasi di atas kemudian dianalisis di Laboratorium Fisika FMIPA UNIPA. Hasil analisis DHL dapat dilihat pada tabel 1 .

Tabel 1. Konsentrasi $\mathrm{NaCl}$ dan daya hantar listrik

\begin{tabular}{ccc}
\hline Konsentrasi (M) & DHL (mS) & $\begin{array}{c}\text { Kadar } \\
\text { Garam (\%) }\end{array}$ \\
\hline 0 & 0,07 & 0,00 \\
0,001 & 0,097 & 0,00 \\
0,01 & 0,287 & 0,02 \\
0,1 & 6,13 & 0,33 \\
1 & 73,4 & 4,75 \\
10 & 180,3 & 15,7 \\
\hline
\end{tabular}

Pengukuran DHL dan kadar garam dengan menggunakan Lutron WA2017SD, bahwa HDL tertinggi yaitu pada konsentrasi $10 \mathrm{M}$ dengan nilai $180,3 \mathrm{mS}$ dan kadar garamnya 15,7\%. Sedangkan yang terendah pada konsentrasi $0,001 \mathrm{M}$ $\mathrm{NaCl}$ dengan nilai $0,097 \mathrm{mS}$, alat Lutron WA-2017SD kurang sensitif untuk mengukur kadar garam untuk konsentrasi $0,001 \mathrm{M} \mathrm{NaCl}$ sehingga kadar garamnya $0,00 \%$.

\section{Rangkaian Seri}

Setiap sel volta merupakan sumber energi listrik sehingga penyusunan sel volta dan arus listrik dapat ditingkatkan melalui pengukuran rangkaian listrik. Jika sel sumber dirangkai secara seri maka akan menaikkan potensial listrik (Giancoli 1991). Pengukuran potensial listrik yang dirangkai secara seri dengan menggunakan enam sel volta dengan elektrolit air garam pada beberapa konsentrasi ditunjukkan pada gambar 2 . 


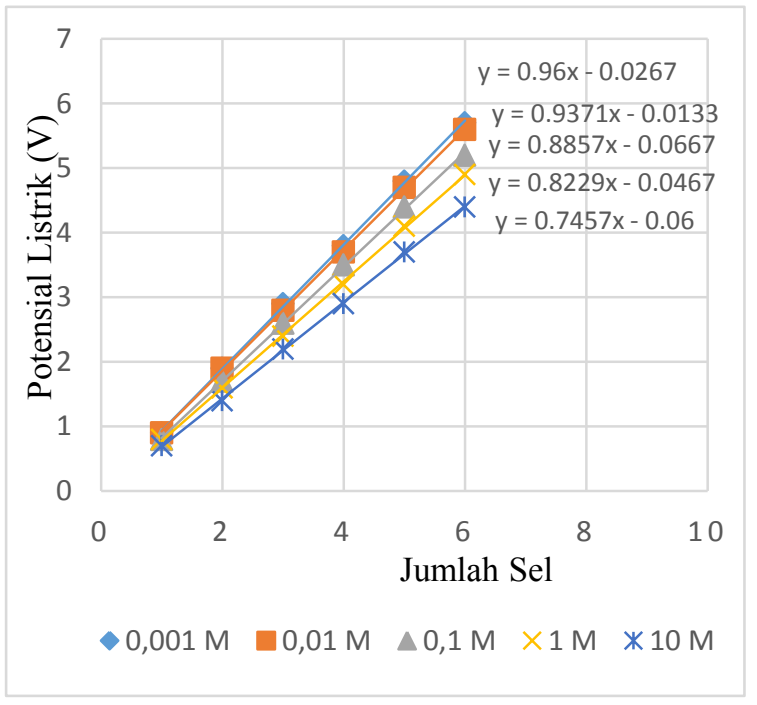

Gambar 2. Hubungan jumlah sel terhadap potensial listrik pada rangkaian seri.

Berdasarkan gambar 2 memperlihatkan bahwa setiap penambahan satu sel volta secara seri akan menaikkan tegangan sebesar 0,96 V untuk air garam pada konsentrasi $0,001 \mathrm{M}$, tegangan 0,93 $\mathrm{V}$ untuk air garam pada konsentrasi 0,01 $\mathrm{M}$, tegangan pada $0,88 \mathrm{~V}$ untuk air garam pada konsentrasi $0,1 \mathrm{M}$, tegangan sebesar $0,82 \mathrm{~V}$ untuk air garam pada konsentrasi 1 $\mathrm{M}$ dan tegangan pada $0,74 \mathrm{~V}$ untuk air garam pada konsentrasi $10 \mathrm{M}$.

\section{Rangkaian Paralel}

Penyusunan sel volta secara paralel akan menaikan arus listrik di dalam sistem. Pengukuran arus listrik yang dirangkai secara paralel dengan menggunakan enam sel volta dengan elektrolit air garam pada beberapa konsentrasi ditunjukkan pada gambar 3

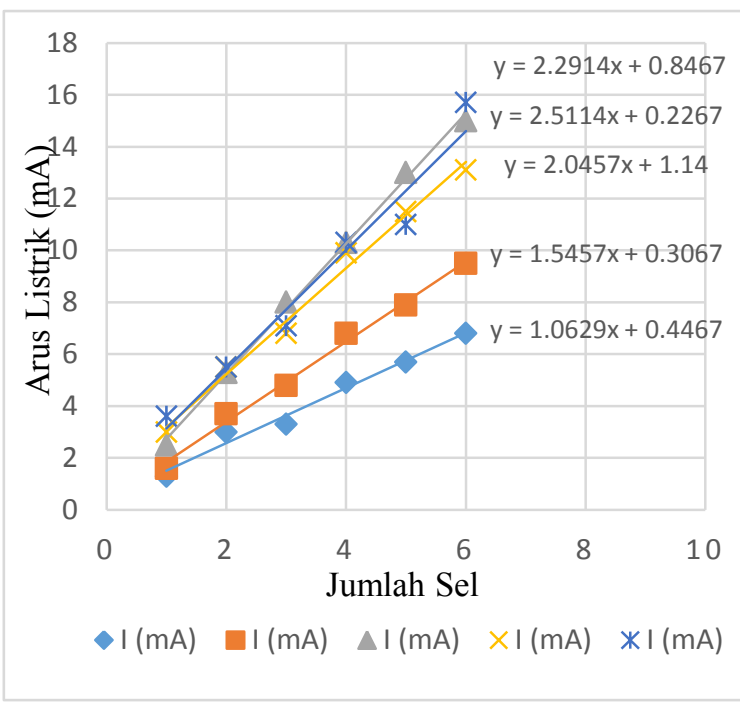

Gambar 3. Hubungan jumlah sel terhadap arus listrik pada rangkaian paralel.

Berdasarkan gambar 3 dengan luas penampang $50 \mathrm{~cm}^{2}$ dan menggunakan beberapa konsentrasi $\mathrm{NaCl}$, memperlihatkan bahwa pada konsentrasi $\mathrm{NaCl}$ 0,001 M menghasilkan arus sebesar $1,06 \mathrm{~mA}$, konsentrasi $\mathrm{NaCl} 0,01 \mathrm{M}$ menghasilkan arus sebesar 1,54 mA, konsentrasi $\mathrm{NaCl}$ 0,1 $\mathrm{M}$ menghasilkan arus listrik sebesar 2,51 mA. Pada konsentrasi 1 $\mathrm{M}$ menghasilkan arus listrik sebesar 2,04 $\mathrm{mA}$ dan konsentrasi $\mathrm{NaCl} 10 \quad \mathrm{M}$ menghasilkan arus listrik sebesar 2,29 mA.

\section{Arus Listrik, Potensial Listrik dan Daya}

\section{Listrik Terhadap Waktu}

a. Konsentrasi $\mathrm{NaCl}$ 0,001 Molar

Pengujian sel volta sebagai sumber energi listrik, dilakukan dengan menggunakan 6 sel volta yang elektrolitnya dari air garam, dirangkai secara seri dan diberi beban lampu LED 1,2 Watt. 
Perubahan arus listrik, potensial listrik dan daya listrik terhadap waktu dengan beban lampu LED 1,2 W yang dirangkai secara seri ditampilkan pada gambar 4

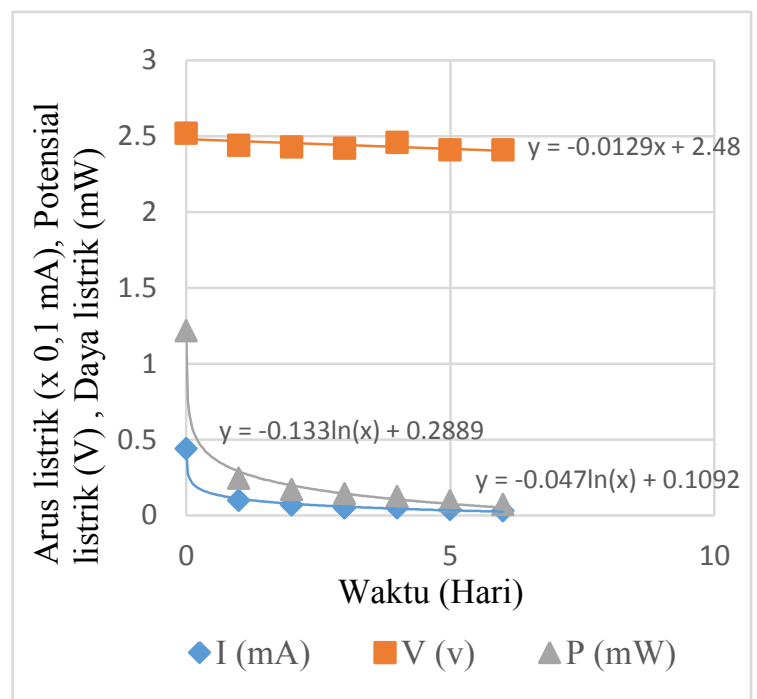

Gambar 4. Perubahan Arus Listrik, Potensial Listrik dan Daya Listrik dengan Konsentrasi 0,001 M Selama Rangkaian Diberikan Beban Berupa Lampu LED

Potensial listrik mula-mula dari 6 buah sel volta yang dirangkai secara seri tanpa beban adalah sebesar 5,46 V sedangkan potensial listrik mula-mula dengan adanya beban $2,48 \mathrm{~V}$ dan arus listrik yang melewati beban adalah sebesar 0,047 mA. Pada gambar 4 terlihat bahwa potensial listrik yang melewati beban turun sangat kecil yaitu sebesar 0,012 per hari sedangkan arus listrik turun secara logaritma. Arus listrik turun $40 \%$ setelah pemakaian 2,5 hari dan daya listrik turun juga secara logaritma. Penurunan daya listrik adalah sebesar 0,133 per hari.

b. Konsentrasi $\mathrm{NaCl}$ 0,01 Molar

Pengujian sel volta sebagai sumber energi listrik, dilakukan dengan menggunakan 6 sel volta yang elektrolitnya dari air garam, dirangkai secara seri dan diberi beban lampu LED
1,2 Watt. Perubahan arus listrik, potensial listrik dan daya listrik terhadap waktu dengan beban lampu LED 1,2 watt yang dirangkai secara seri ditampilkan pada gambar 5

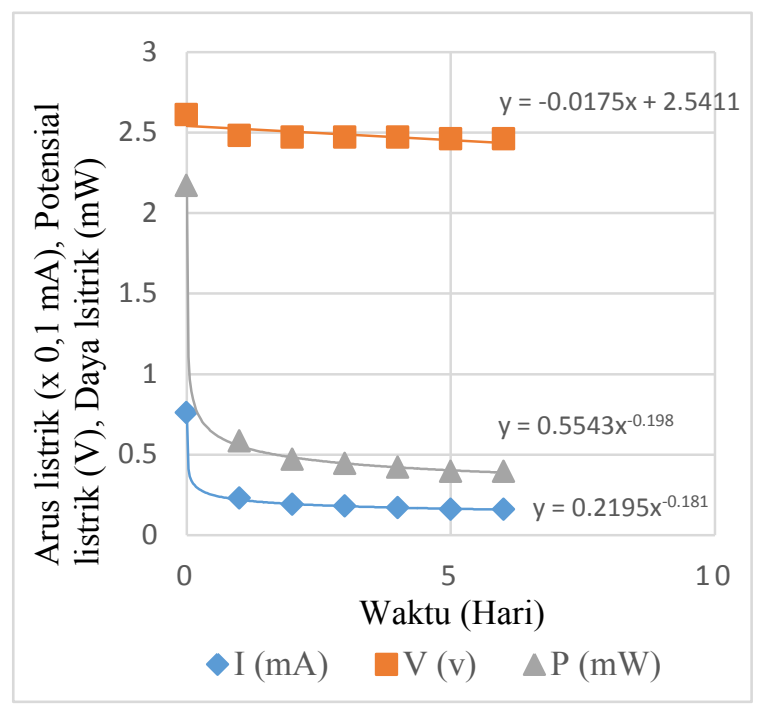

Gambar 5. Perubahan Arus Listrik, Potensial Listrik dan Daya Listrik dengan Konsentrasi 0,01 M Selama Rangkaian Diberikan Beban Berupa Lampu LED

Potensial listrik mula-mula dari 6 buah sel volta yang dirangkai secara seri tanpa beban adalah sebesar 5,26 V sedangkan potensial listrik mula-mula dengan adanya beban $2,487 \mathrm{~V}$ dan arus listrik yang melewati beban adalah sebesar 0,219 mA. Pada gambar 5 terlihat bahwa potensial listrik yang melewati beban turun sangat kecil yaitu sebesar 0,017 per hari sedangkan arus listrik turun secara power. Arus listrik turun $40 \%$ setelah pemakaian 2,5 hari dan daya listrik turun juga secara power. Penurunan daya listrik adalah sebesar 0,554 per hari.

c. Konsentrasi $\mathrm{NaCl}$ 0,1 Molar.

Pengujian sel volta sebagai sumber energi listrik, dilakukan dengan 
menggunakan 6 sel volta yang elektrolitnya dari air garam, dirangkai secara seri dan diberi beban lampu LED 1,2 Watt. Perubahan arus listrik, potensial listrik dan daya listrik terhadap waktu dengan beban lampu LED 1,2 watt yang dirangkai secara seri ditampilkan pada gambar 6

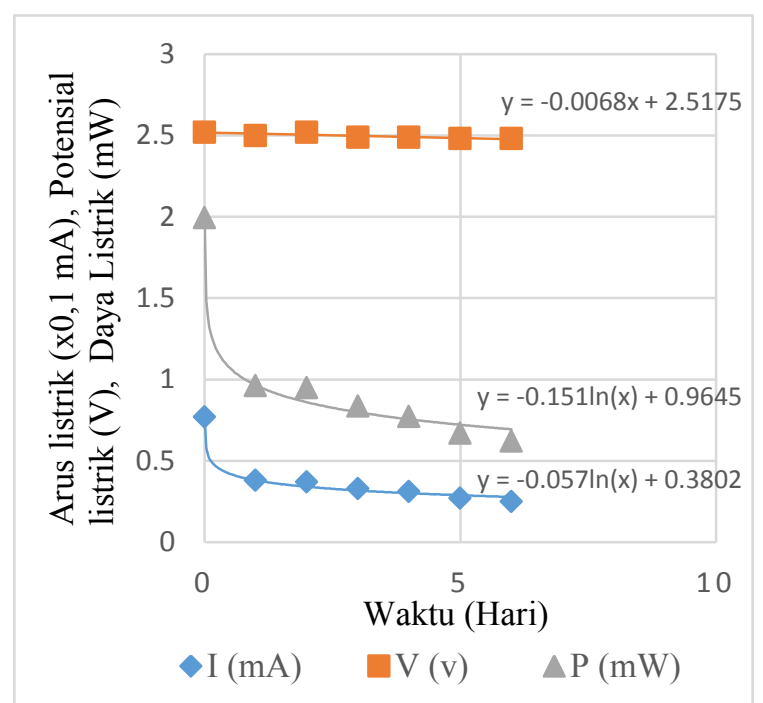

Gambar 6. Perubahan Arus Listrik, Potensial Listrik dan Daya Listrik dengan Konsentrasi 0,1 M Selama Rangkaian Diberikan Beban Berupa Lampu LED

Potensial listrik mula-mula dari 6 buah sel volta yang dirangkai secara seri tanpa beban adalah sebesar 5,19 V sedangkan potensial listrik mula-mula dengan adanya beban $2,51 \mathrm{~V}$ dan arus listrik yang melewati beban adalah sebesar 0,057 mA. Pada gambar 6 terlihat bahwa potensial listrik yang melewati beban turun sangat kecil yaitu sebesar 0,0068 per hari sedangkan arus listrik turun secara logaritma. Arus listrik turun $40 \%$ setelah pemakaian 2,5 hari dan daya listrik turun juga secara logaritma. Penurunan daya listrik adalah sebesar 0,151 per hari. d. Konsentrasi NaCl 1 Molar.

Pengujian sel volta sebagai sumber energi listrik, dilakukan dengan menggunakan 6 sel volta yang elektrolitnya dari air garam, dirangkai secara seri dan diberi beban lampu LED 1,2 Watt. Perubahan arus listrik, potensial listrik dan daya listrik terhadap waktu dengan beban lampu LED 1,2 watt yang dirangkai secara seri ditampilkan pada gambar 7

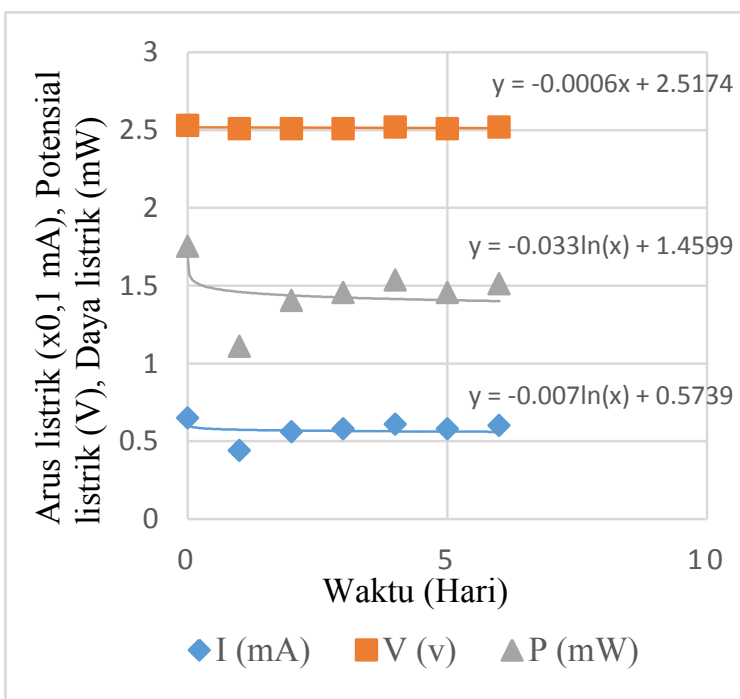

Gambar 7. Perubahan Arus Listrik, Potensial Listrik dan Daya Listrik dengan Konsentrasi 1 M Selama Rangkaian Diberikan Beban Berupa Lampu LED

Potensial listrik mula-mula dari 6 buah sel volta yang dirangkai secara seri tanpa beban adalah sebesar 4,92 V sedangkan potensial listrik mula-mula dengan adanya beban $2,51 \mathrm{~V}$ dan arus listrik yang melewati beban adalah sebesar 0,007 mA. Pada gambar 7 terlihat bahwa potensial listrik yang melewati beban turun sangat kecil yaitu sebesar 0,006 per hari sedangkan arus listrik turun secara logaritma. Arus listrik turun $40 \%$ setelah pemakaian 2,5 hari dan daya listrik turun juga secara logaritma. Penurunan daya listrik adalah sebesar 0,033 per hari. 
e. Konsentrasi NaCl 10 Molar.

Pengujian sel volta sebagai sumber energi listrik, dilakukan dengan menggunakan 6 sel volta yang elektrolitnya dari air garam, dirangkai secara seri dan diberi beban lampu LED 1,2 Watt. Perubahan arus listrik, potensial listrik dan daya listrik terhadap waktu dengan beban lampu LED 1,2 Watt yang dirangkai secara seri ditampilkan pada gambar 8

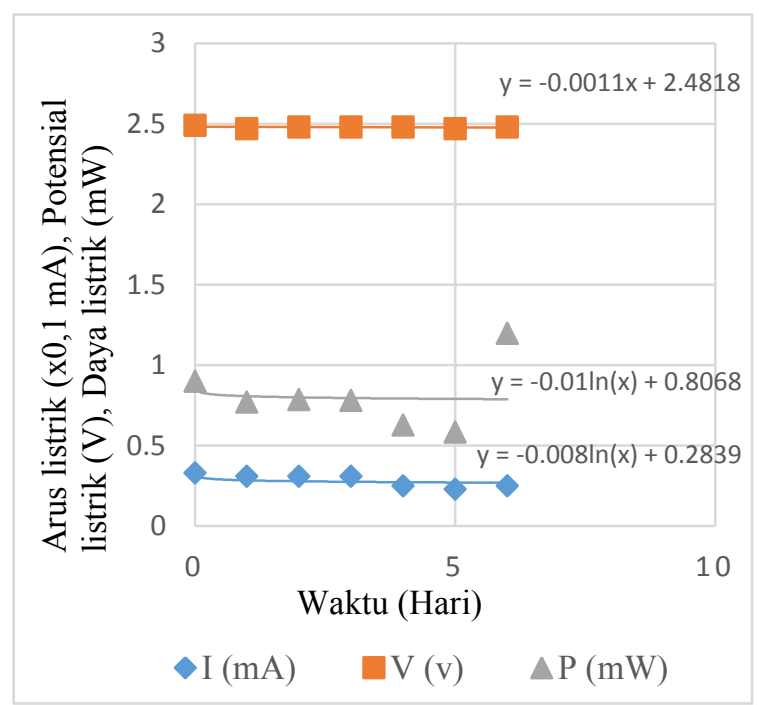

Gambar 8. Perubahan Arus Listrik, Potensial Listrik dan Daya Listrik dengan Konsentrasi 10 M Selama Rangkaian Diberikan Beban Berupa Lampu LED

Potensial listrik mula-mula dari 6 buah sel volta yang dirangkai secara seri tanpa beban adalah sebesar 4,70 V sedangkan potensial listrik mula-mula dengan adanya beban $2,48 \mathrm{~V}$ dan arus listrik yang melewati beban adalah sebesar 0,008 mA. Pada gambar 8 terlihat bahwa potensial listrik yang melewati beban turun sangat kecil yaitu sebesar 0,001 per hari sedangkan arus listrik turun secara logaritma. Arus listrik turun $40 \%$ setelah pemakaian 2,5 hari dan daya listrik turun juga secara logaritma. Penurunan daya listrik adalah sebesar 0,01 per hari.
Dari kelima konsentrasi $\mathrm{NaCl}(0,001$ $\mathrm{M} ; 0,01 \mathrm{M} ; 0,1 \mathrm{M} ; 1 \mathrm{M}$ dan $10 \mathrm{M}$ ) memperlihatkan bahwa terjadi penurunan arus listrik dan daya listrik terhadap waktu semakin menurun dari hari pertama sampai hari keenam.

Pada beberapa variasi konsentrasi $\mathrm{NaCl}$ penurunan arus terhadap waktu ditunjukkan pada gambar 9

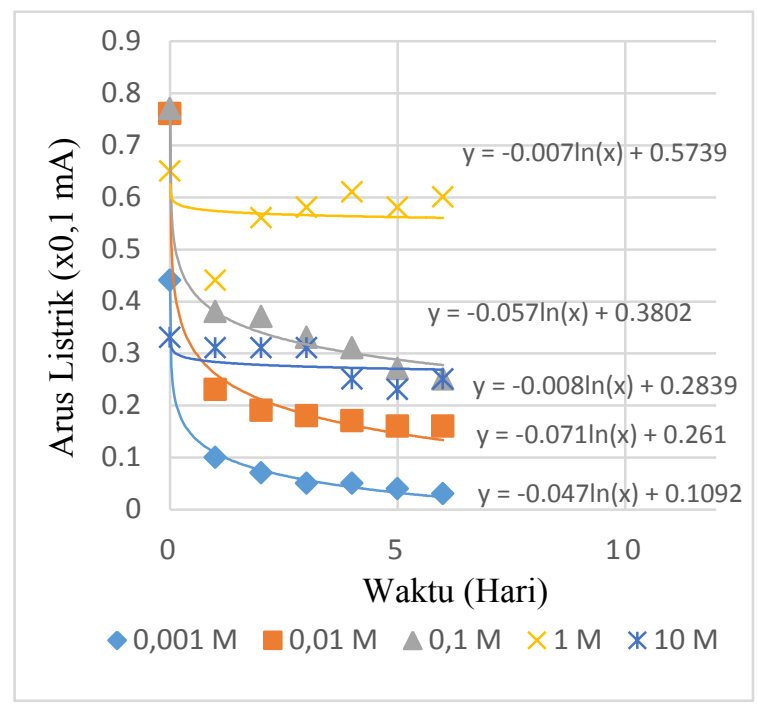

Gambar 9. Arus Listrik dengan Beberapa Konsentrasi $\mathrm{NaCl}$ Terhadap Waktu

Pada gambar 9 terlihat bahwa pada kelima konsentrasi diberikan beban LED 1,2 Watt memperlihatkan penurunan arus listrik terbesar terjadi pada konsentrasi 0,001 M, 0,01 M dan 0,1 M. Hal ini bisa terlihat dari koefisien ketiga persamaan tersebut. penurunan yang tajam dari ketiga konsentrasi tersebut akibat dari kebutuhan beban listrik sebesar 1,2 W tidak dapat diimbangi oleh laju reaksi pada sel volta pada ketiga konsentrasi tersebut. Penurunan terbesar terjadi pada konsentrasi 0,001 M pada konsentrasi $1 \mathrm{M}$ dan $10 \mathrm{M}$ penurunannya kecil atau relatif stabil perubahan listrik terhadap waktu. Hal ini bisa terlihat dari koefisien kedua 
persamaan tersebut. Arus listrik terbesar pada konsentrasi $1 \mathrm{M}$. Pada $1 \mathrm{M}$ dan $10 \mathrm{M}$ relatif lebih stabil karena terjadi laju reaksi antara ion dan elektroda didalam sel volta dapat mengimbangi beban listrik sekitar $1,2 \mathrm{~W}$.

\section{Daya Listrik}

Daya listrik adalah jumlah energi per satuan waktu yang dihasilkan dalam sebuah rangkaian. Setelah melakukan pengambilan data potensial listrik dan arus listrik yang dihasilkan oleh air garam, maka selanjutnya dapat menghitung daya listrik tersebut. Energi listrik dihasilkan dari perbedaan tegangan dan arus listrik mengalir karena adanya perbedaan tegangan tersebut. Pengukuran daya listrik dengan beberapa konsentrasi $\mathrm{NaCl}$ ditunjukkan pada gambar 10

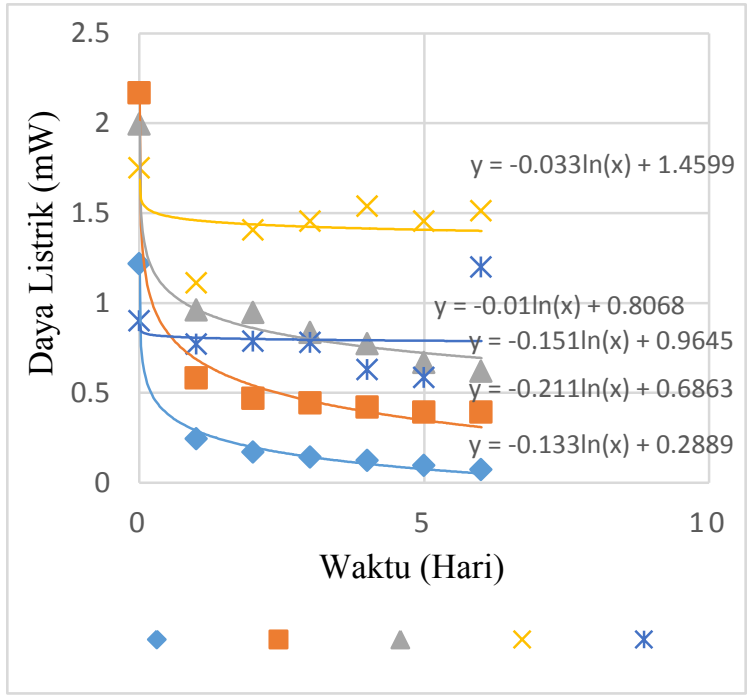

Gambar 10. Daya Listrik Terhadap Waktu

Daya listrik diperoleh dari perhitungan potensial listrik dikalikan dengan arus listrik. Potensial listrik relatif stabil terhadap waktu sedangkan arus listrik berubah terhadap waktu. Penurunan arus listrik terbesar terjadi pada konsentrasi 0,001 M, 0,01 M, 0,1 M. Hasil penelitian Pauzi dkk (2018) juga memperlihatkan arus listrik dan daya listrik mengalami penurunan yang tajam pada 3 jam petama didalam sel volta dengan larutan $\left(\mathrm{NaHCO}_{3}\right)$ sedangkan tegangan tetap konstan. Hal ini menyebabkan daya listrik juga turun dengan cepat pada ketiga konsentrasi tersebut. konsentrasi $1 \mathrm{M}$ dan $10 \mathrm{M}$ memiliki daya yang lebih besar karena perubahan tegangan listrik dan arus listrik relatif lebih kecil. Daya listrik terbesar terjadi pada konsentrasi 1 M. Hasil penelitian Azhari (2019) pada sel volta dengan larutan $\mathrm{CuSO}_{4}$ dan larutan $\mathrm{ZnSO}_{4}$ pada konsentrasi $0,2 \mathrm{M}, 0,5 \mathrm{M}$ dan $1 \mathrm{M}$ memperlihatkan bahwa daya tertinggi terjadi pada konsentrasi $1 \mathrm{M}$.

\section{Akumulasi Energi}

Energi listrik adalah energi yang berkaitan dengan akumulasi arus elektron, dinyatakan dalam watt-jam. Bentuk transisinya adalah aliran elektron melalui konduktor jenis tertentu. Energi listrik dapat disimpan sebagai medan elektromagnetik yang merupakan energi yang berkaitan dengan medan listrik yang dihasilkan karena terakumulasi muatan elektron pada pelat-pelat kapasitor. Pengukuran akumulasi energi dengan beberapa konsentrasi $\mathrm{NaCl}$ ditunjukkan pada gambar 11

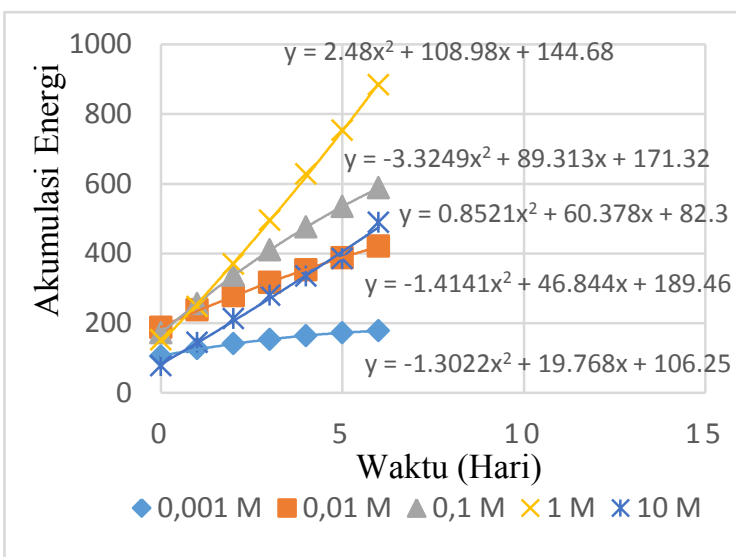

Gambar 11. Akumulasi Energi Terhadap Waktu 
Gambar $11 \quad$ Memperlihatkan kenaikan akumulasi energi sejalan dengan kenaikan konsentrasi $\mathrm{NaCl}$ hingga $1 \mathrm{M}$ sedangkan pada konsentrasi $10 \mathrm{M}$ akumulasi energinya menurun. Penurunan akumulasi energi dari konsentrasi $10 \mathrm{M}$ disebabkan oleh konsentrasi ion pada elektroda. Tumpukan kation pada elektroda terutama pada anoda umumnya terjadi pada elektrolit konsentrasi tinggi. Akumulasi energi yang tinggi pada konsentrasi $1 \mathrm{M}$ jika dibandingkan dengan konsentrasi yang lain. Dapat dilihat bahwa arus listrik dari konsentrasi $1 \mathrm{M}$ lebih besar dari konsentrasi lain dan stabil sehingga akumulasi energi masih naik secara linear hingga hari keenam pengamatan. Jika dibandingkan dengan konsentrasi lain yang sudah mulai menurun pada hari keenam. Dapat disimpulkan bahwa konsentrasi $\mathrm{NaCl} 1 \mathrm{M}$ merupakan konsentrasi terbaik pada sistem sel volta $\mathrm{Cu}-\mathrm{Zn}$ untuk menghasilkan energi listrik.

\section{Variasi Konsentrasi Terhadap Arus Listrik, Potensial Listrik dan Daya Listrik.}

\section{a. Rangkaian Seri}

Penyusunan sel volta secara seri terhadap variasi konsentrasi $\mathrm{NaCl}$ dengan menggunakan enam sel volta. Perubahan arus listrik, potensial listrik dan daya listrik terhadap variasi konsentrasi dari 0,001 $\mathrm{M}$ sampai dengan $10 \mathrm{M}$ ditunjukkan pada gambar 12

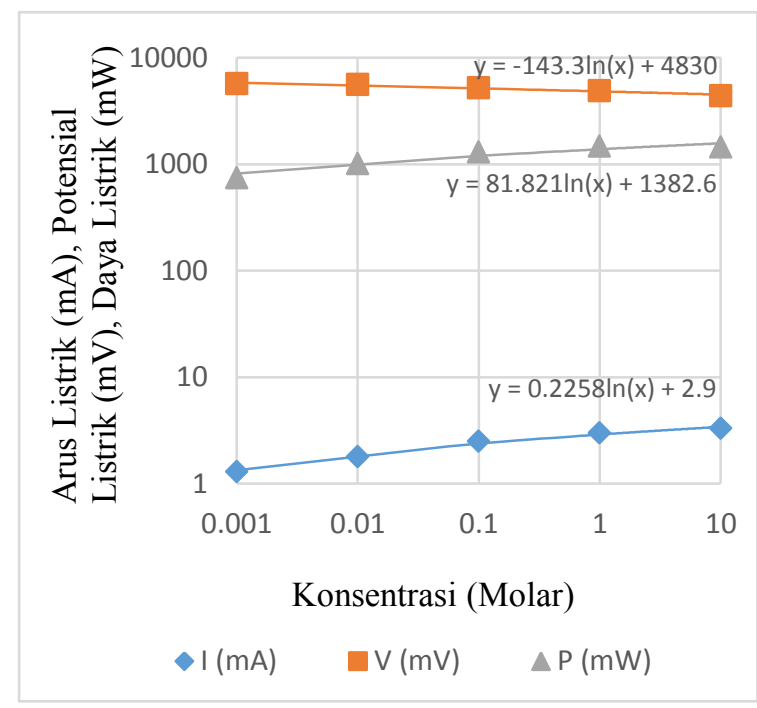

Gambar 12. Perubahan Arus Listrik, Potensial Listrik dan Daya Listrik dengan Variasi Konsentrasi $\mathrm{NaCl}$ Pada Rangkaian Seri.

Pada gambar 12 memperlihatkan perubahan arus listrik terhadap konsentrasi dengan menggunakan 6 sel volta yang dirangkai secara seri dengan nilai 0,2258 $\mathrm{mA}$ untuk setiap perubahan konsentrasi dari $0,001 \mathrm{M}$ sampai dengan $10 \mathrm{M}$ dan arus listrik terjadi secara logaritma sedangkan untuk perubahan potensial listrik terhadap konsentrasi dengan nilai 143,3 $\mathrm{mV}$ dan terjadi penurunan secara logaritma pada perubahan daya listrik terhadap konsentrasi dengan nilai 81,821 $\mathrm{mW}$ setiap perubahan $0,001 \mathrm{M}$ sampai dengan $10 \mathrm{M}$. Sehingga dapat disimpulkan bahwa konsentrasi mempengaruhi perubahan arus listrik, potensial listrik dan daya listrik yang dihasil dari setiap masing-masing konsentrasi yang dihasilkan sebagai sumber energi listrik alternatif.

\section{b. Rangkaian Paralel}

Penyusunan sel volta secara paralel terhadap variasi konsentrasi $\mathrm{NaCl}$ dengan menggunakan enam sel volta. Perubahan 
arus listrik, potensial listrik dan daya listrik terhadap variasi konsentrasi dari 0,001 $\mathrm{M}$ sampai dengan $10 \mathrm{M}$ ditunjukkan pada gambar 13

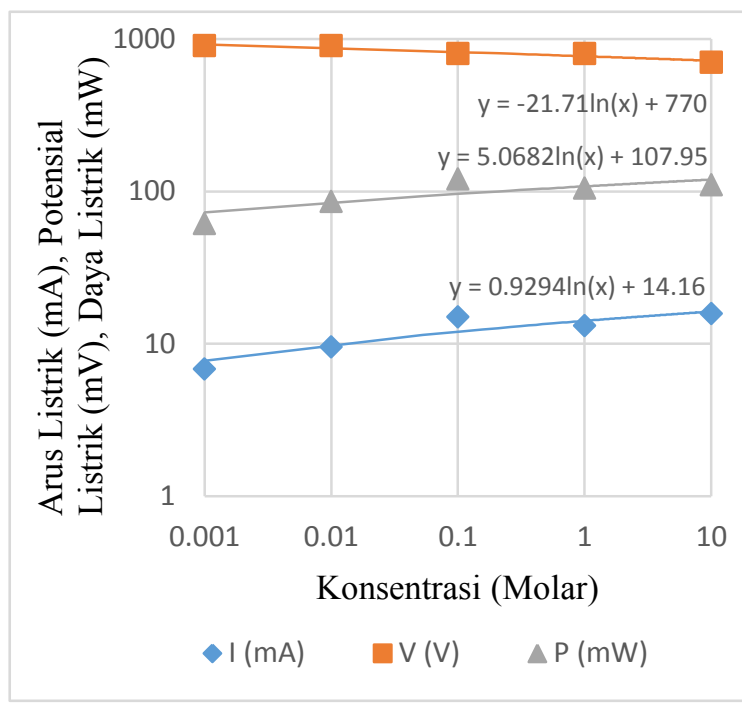

Gambar 13. Perubahan Arus Listrik, Potensial Listrik dan Daya Listrik dengan Variasi Konsentrasi $\mathrm{NaCl}$ Pada Rangkaian Paralel.

Pada gambar 13 memperlihatkan perubahan arus listrik terhadap konsentrasi dengan menggunakan 6 sel volta yang dirangkai secara seri dengan nilai 0,9294 $\mathrm{mA}$ untuk setiap perubahan konsentrasi dari $0,001 \mathrm{M}$ sampai dengan $10 \mathrm{M}$ dan arus listrik terjadi secara logaritma sedangkan untuk perubahan potensial listrik terhadap konsentrasi dengan nilai 21,71 $\mathrm{mV}$ dan terjadi penurunan secara logaritma pada perubahan daya listrik terhadap konsentrasi dengan nilai 5,0682 $\mathrm{mW}$ setiap perubahan $0,001 \mathrm{M}$ sampai dengan $10 \mathrm{M}$. Sehingga dapat disimpulkan bahwa konsentrasi mempengaruhi perubahan arus listrik, potensial listrik dan daya listrik yang dihasil dari setiap masing-masing konsentrasi yang dihasilkan sebagai sumber energi listrik alternatif.

\section{KESIMPULAN}

Berdasarkan hasil dan pembahasan data penelitian, diambil kesimpulan sebagai berikut:

1. Konsentrasi garam dan daya hantar listrik lebih tinggi konsentrasi $10 \mathrm{M}$ dibandingkan dengan konsentrasi 0,001 M.

2. Setiap penambahan satu sel volta pada rangkaian seri potensial listrik yang dihasilkan akan semakin kecil hal ini disebabkan semakin banyak jumlah konsentrasi $\mathrm{NaCl}$ akan mempengaruhi potensial listrik. Sehingga pada konsentrasi $\mathrm{NaCl}$ 0,001 $\mathrm{M}$ menghasilkan tegangan listrik sebesar $0,96 \mathrm{~V}$ sedangkan pada konsentrasi $\mathrm{NaCl} \quad 10 \quad \mathrm{M}$ menghasilkan tegangan listrik sebesar 0,74 V. Penambahan satu sel volta pada rangkaian seri tidak mempengaruhi arus listrik di dalam sistem sel volta sedangkan pada rangkaian paralel konsentrasi $\mathrm{NaCl}$ 0,001 M menghasilkan arus listrik sebesar 1,06 mA sedangkan pada konsentrasi $10 \mathrm{M}$ menghasilkan arus listrik sebesar 2,29 mA. Sehingga pada setiap penambahan sel volta terhadap konsentrasi $\mathrm{NaCl}$ arus listrik yang dihasilkan semakin meningkat. Penambahan satu sel volta pada rangkaian paralel tidak 
mempengaruhi potensial listrik di dalam sistem sel volta.

3. Pada konsentrasi $\mathrm{NaCl} \quad 0,001 \mathrm{M}$ menghasilkan arus listrik sebesar 0,0047 $\mathrm{mA}$ dan tegangan listrik sebesar 2,48 $\mathrm{V}$ maka daya listrik yang dihasilkan sebesar $0,133 \mathrm{~mW}$ sedangkan konsentrasi $\mathrm{NaCl} 10 \mathrm{M}$ menghasilkan arus listrik sebesar 0,008 $\mathrm{mA}$ dan tegangan listrik sebesar 2,48 V maka daya listrik yang dihasilkan sebesar $0,01 \mathrm{~mW}$. Sehingga semakin besar arus listrik dan tegangan listrik daya yang dihasilkan akan semakin besar.

4. Pada konsentrasi $\mathrm{NaCl} 0,001 \mathrm{M}$ nilai akumulasi energi minimum yang diperoleh yaitu sebesar 178,487 J sedangkan pada konsentrasi $\mathrm{NaCl} 1$ $\mathrm{M}$ nilai akumulasi energi maksimum yang diperoleh yaitu sebesar 883,897 J.

\section{DAFTAR PUSTAKA}

Azhari. H. 2019. Analisis Potensi Energi Alternatif dengan Metode Galvanic Cell Sebagai Sumber Energi CHEME-CAR. Universitas Muhammadiyah Surakarta. Skripsi.

Giancoli, D. C. 1991. Physics. Pretince Hall International Edition.

Giancoli. 1998. Fisika Edisi Kelima Jilid 2. Erlangga. Jakarta. Hal 61-68.

Hariyani U., Rupiasih N. N., Kasmawan I. G. A., 2013. Pengaruh Konsentrasi dan Ion Valensi Larutan Terhadap Rapat Arus Difusi Ion Pada Membran Kitosan. Vol 14, 67-72.

Latifah, D. 2014. Analisis Daya Hantar Listrik (DHL) AirTanah Asin dan Dampak Pada Peralatan Rumah Tangga Di Kecamatan Grogol. Skripsi. Universitas Muhammadiyah Surakarta.

Pauzi. G. A., Hudaya E., Suprianto A., Warsito. 2016. Analisis Uji Karakteristik Elektrik Air Laut Sebagai Sumber Energi Listrik Terbarukan. Proseding SN SMIAP 2016.

Pauzi. G. A., Arwaditha .R. K., Supriyanto A., Suciyati S.W., Surtono A., Junaidi., Warsito. 2018. Desaian dan Realisasi Akumulator Elektrolit Air Laut dengan Penambahan Sodium Bicarbonate $\left(\mathrm{NaHCO}_{3}\right)$ Sebagai Sumber Energi Alternatif. Jurnal Fisika 8 (2) 2018.

Sani, A. 2018. Analisa Baterai Air Asin Dengan Elektroda Tembaga Dan Aluminium. Skripsi, Jurusan Teknik Elektro Fakultas Teknik Universitas Muhammadiyah Surakarta.

Sastrohamidjojo, H. 2005. Kimia Dasar. Yogyakarta

Yulianti, D. 2016. Analisis Kelistrikan Sel Volta Memanfaatkan Logam Bekas. Lampung Universitas Lampung.

Zikriana L., Hamid A, 2017. Perbandingan Tegangan Yang Diberi Larutan Garam Dengan Massa Yang Berbeda Untuk Menggerakkan Kipas Angin Sederhana. 
